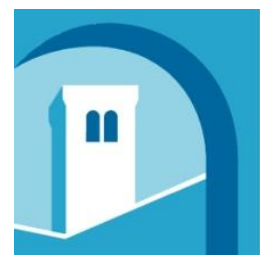

European

University

Institute

European Journal of Legal Studies

Title: Recognition of Contracts as Investments in International Investment Arbitration

Author(s): Velimir Zivkovic

Source: European Journal of Legal Studies, Volume 5, Issue 1 (Spring/Summer 2012), p. 174-192

\begin{abstract}
:
The issue of recognition of contractual rights as protected investments in international investment arbitration, primarily under the auspices of ICSID, has sparked divergent approaches in case law. Treatment of certain contracts and the criteria used differ, which leads to unwelcome consequence of lowering legal certainty in a very sensitive issue. The aim of this paper is to contribute to enhancement and clarification of legal reasoning in this area, with a special focus on the criteria to be used and on sales contracts which are particularly controversial in practice. This is done through the analysis of the current state of affairs which is followed by a proposition of a new model of criteria which could present a beneficial compromise between the existing models and increase certainty.
\end{abstract}


Article

\title{
RECOGNITION OF CONTRACTS AS INVESTMENTS IN INTERNATIONAL INVESTMENT ARBITRATION
}

\author{
Velimir Zivkovic* \\ TABLE OF CONTENTS
}

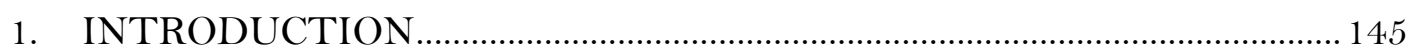

2. RECOGNITION OF CONTRACTS AS INVESTMENTS ............................. 146

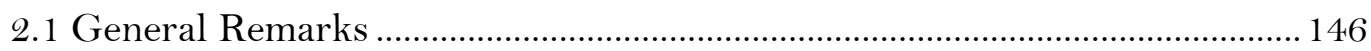

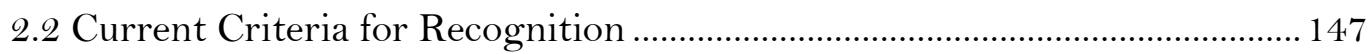

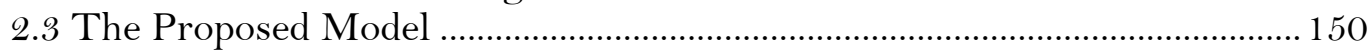

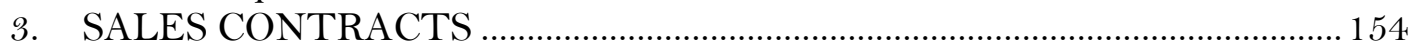

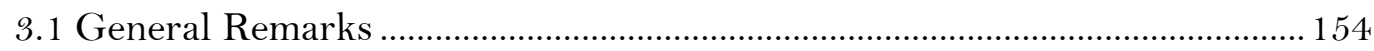

3.2 Sales Contracts which Deserve Recognition.................................................... 156

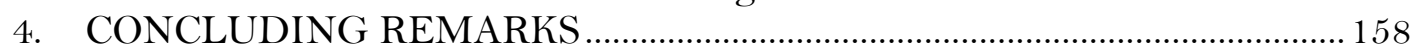

* LL.M, MJur (Oxon). PhD Candidate in Business Law, University of Belgrade Faculty of Law and a Technical Expert at OPTIMUS Center for Good Governance in Belgrade. 


\section{INTRODUCTION}

The issue of what can be recognized as an investment and given the corresponding protection under the rules of international investment law is both long lasting and highly contentious. While categories of investments which can be deemed easily recognizable' do exist, they only form a (relatively) stable core of the term. Its outer limits are far from settled.

Contractual rights are a good example of the shifting boundaries of investment protection. Historically, the recognition of possibility of international law regime to deal with contracts including private entities, started with the Serbian Loans case of the Permanent Court of International Justice in $1929,{ }^{1}$ was an impetus that eventually grew to creation of investment dispute settlement mechanisms we recognize today. ${ }^{2}$ Even before that, Permanent Court of Arbitration recognized the possibility to expropriate contractual rights as assets in Norwegian Shipowners'

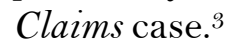

Despite widespread contemporary acceptance of intangible assets (and indeed contractual rights) as protected investments in international investment law, the key question - which contractual rights are to be protected? - is not decisively settled. Actual examples from the practice of investment protection offer intriguing examples of dilemmas that need to be solved - is commercialization of tobacco products a form of investment? What about contracts for retrieving shipwrecked artefacts and selling them later? Or maybe expenditures made prior to actually obtaining a contract with a host state? The debate about these issues is, of course, far from a purely academic one. Recognizing that a certain contractual right (or as is commonly abbreviated, 'contract') is a protected investment can mean a world of difference for a foreign investor in terms of available protection. It can mean a difference between litigating in a possibly slow and/or biased court system of a host State and having recourse to arbitral proceedings before a specialised and wellknown international institution such as International Centre for Settlement of Investment Disputes (ICSID). The topic of this paper is to contribute to enhancement and clarification of legal reasoning in this area, with a special focus on the criteria to be used and also on sales contracts, a category which is particularly controversial in practice.

The discussion ahead consists of three parts. The first part deals with the general issues of recognizing a contract as a protected 'investment' and also explores the broader issue of the criteria used to recognize protected investments in international investment arbitration and the proposed future model of recognizing investments. The second part is focused on sales contracts, their current status and the potential use of the suggested model when facing the issue if a particular sales contract is an investment or not. The third part proposes certain guidelines for the future regarding the discussed issues. These guidelines are based on the conclusions reached in previous parts.

\footnotetext{
${ }^{1}$ Payment of Various Serbian Loans Issued in France (France v Yugoslavia), PCIJ Rep Series No 20. ${ }^{2}$ Thomas Wälde, 'The Serbian Loans Case: A Precedent for Investment Treaty Protection of Foreign Debt?' in Todd Weiler (ed), International Investment Law and Arbitration: Leading Cases from the ICSID, NAFTA, Bilateral Treaties and Customary International Law (Cameron May 2005) 393.

${ }^{3}$ Permanent Court of Arbitration Norwegian Shipowners' Claims (Award,13 October 1922) 1 RIAA 307. See also August Reinisch, 'Expropriation' in Peter Muchlinski, Federico Ortino and Christoph Schreuer (eds), The Oxford Handbook of International Investment Law (OUP 2008) 411-412.
} 


\section{RECOGNITION OF CONTRACTS AS INVESTMENTS}

\subsection{General Remarks}

Contractual rights are often present in investment disputes. This is in accordance with the general trend of the changing nature of investments, which is evolving from the old natural resource exploitation and ownership of production facilities to more modern forms, such as service agreements. ${ }^{4}$

It is possible to make a list of commonly encountered forms of contract. The types of contracts usually considered as having a character of investment in bilateral investment treaties (BITs) when listed, ICSID practice and doctrinal writings are: construction, turnkey, management/service, production, profit-sharing, leasing, technology/know-how transfer, and joint-venture contracts. ${ }^{5}$ Other important contracts are public concession agreements, but one should bear in mind that they by their nature include the host State and thus generally pose no particular problems in being identified as protected by international investment law. Some authors include loans in the group of protected contracts, ${ }^{6}$ which is technically true (loans are, of course, contracts), but they are usually classified as a separate group of investments along with other financial instruments.

But the above is merely an informative list, a recapitulation of what can be found in legal instruments and case law. The key issue is not just to identify these contracts. The crucial question is why are these contracts recognized? Only if the criteria which led to this are known and understood properly it can be said that there will be enough predictability to ascertain if in a future case a contractual right is likely to be recognized as an investment. And at this point the analysis necessarily becomes somewhat broader.

The criteria proposed for recognizing contractual rights cannot be separated from the criteria which will be used in general to evaluate if there is an investment. Despite certain specificities (some will be suggested in the section dealing with sales contracts) the underlying core criteria will necessarily be the same for different types of investments. Thus, examining what these criteria are and how the overall approach can be improved has a wider relevance for the notion of 'investment' in international investment law. Of course, due effort will be made to frame the findings and conclusions within the context of contractual rights as much as possible.

\footnotetext{
${ }^{4}$ Muthucumaraswamy Sornarajah, The International Law on Foreign Investment (3rd edn, CUP 2010) 11-6.

${ }^{5}$ Cristoph Schreuer, The ICSID Convention: A Commentary (CUP 2001) 138-139; United States $\begin{array}{llllll}\text { Model Bilateral } & \text { Investment } & \text { Treaty } & \text { C }\end{array}$ http://www.state.gov/documents/organization/188371.pdf > accessed 13 May 2012 (US Model BIT 2012) art 1; Sergey Ripinsky and Kevin Williams, Damages in International Investment Law (British Institute of International and Comparative Law 2008) 102; John P. Given, 'Malaysia Historical Salvors Sdn., Bhd. v. Malaysia: An End to the Liberal Definition of "Investment" in ICSID Arbitrations?' 31 Loyola of Los Angeles International and Comparative Law Review (2009) 467, 475; Prabhash Ranjan, 'Definition of Investment in Bilateral Investment Treaties of South Asian Countries and Regulatory Discretion' 26 Journal of International Arbitration 219, 225. See also OECD, The Multilateral Agreement on Investment: Draft Consolidated Text, DAFFE/MAI(98)7/REV1 11 (MAI) ch 2, art 2.

${ }^{6}$ Given (n 5) 475-6.
} 


\subsection{Current Criteria for Recognition}

Two preliminary notes should be made. Firstly, it is not the author's objective to try and ascertain criteria which led to recognition of certain contracts or other transactions as investments in particular BITs. Bearing in mind their vast number and a plethora of circumstances which might influence specific definitions in particular BITs, such task is indeed out of the scope of this paper. What can be said is that developments in practice do influence BITs and definitions therein, but such influence always has to be examined on a case-by-case basis.

Secondly, the discussion that follows is primarily centred on establishing ICSID jurisdiction and problems with the notion of 'investment' found in Article 25 of the Washington Convention. ${ }^{7}$ One reason for this is that ICSID is (in terms of caseload and dispute values) the most important forum for resolving investment disputes. ${ }^{8}$ The second one is that this sensitive area is currently marred by divergent jurisprudence.

Regarding non-ICSID arbitral tribunals, generally speaking two different situations can exist. In some cases the issues discussed are not so prominent, as there might be no need to deal with Article 25 and parties are generally free to arbitrate about whatever they agree upon (subject, of course, to potentially mandatory rules on arbitrability and similar provisions). In such cases the jurisdiction can be established, for example, merely by interpreting the BIT, which would be the only step that needs to be taken when establishing jurisdiction. In other situations, most prominently NAFTA cases, the situation might again revolve around establishing an objective meaning of the term 'investment'. In such cases, it is legitimate to ask whether or not the discussion of ICSID cases and jurisprudence formed therein might be of influence or even of precedential value? Regarding NAFTA, it can be said that there is a growing tendency to look upon investment treaty arbitration and awards made as a single phenomenon and not to insist on differences between jurisdictions. ${ }^{9}$ Decisions of arbitral tribunals dealing with alleged breaches of NAFTA provisions confirm the tendency to give due consideration and careful examination to previous ICSID awards as well. ${ }^{10}$ Bearing this in mind, it can be said that the discussion that follows can also be of wider (non-ICSID) relevance.

The starting point for dealing with the issues of ICSID jurisdiction is Article 25(1) of the ICSID Convention, which states:

\footnotetext{
7 The Washington Convention on the Settlement of Investment Disputes between States and Nationals of other States (adopted 18 March 1965, entered into force 14 October 1966) 575 UNTS (1965) 159 (The ICSID Convention).

8 Lucy Reed, Jan Paulsson and Nigel Blackaby, Guide to ICSID Arbitration (Kluwer Law International 2010) 7-8; Jan Peter Sasse, An Economic Analysis of Bilateral Investment Treaties (Gabler Verlag 2011) 59.

${ }^{9}$ See Jeffery P. Commission, 'Precedent in Investment Treaty Arbitration - A Citation Analysis of a Developing Jurisprudence’ (2007) 24(2) Journal of International Arbitration 129.

10 Grand River Enterprises Six Nations, Ltd., et al. v. United States of America, NAFTA/UNCITRAL Arbitration Rules Arbitration (Award, 12 January 2011), <http://www.arbitrationlaw.com/files/free_pdfs/Grand\%20River\%20v\%20US\%20-\%20Award.pdf> accessed 15 May 2012, para. 61; The Canadian Cattlemen for Fair Trade v. United States of America, NAFTA/UNCITRAL Arbitration Rules Arbitration (Award on Jurisdiction, 28 January 2008), $<$ http://italaw.com/documents/CCFT-USAAward_Ooo.pdf> accessed 15 May 2012, paras 49-51.
} 
The jurisdiction of the Centre shall extend to any legal dispute arising directly out of an investment, between a Contracting State (or any constituent subdivision or agency of a Contracting State designated to the Centre by that State) and a national of another Contracting State, which the parties to the dispute consent in writing to submit to the Centre...

The term 'investment' (unlike 'national', for example) is not defined in further text. Despite some differing opinions, it is commonly considered that this was not caused by a mere lack of agreement, but was an intentional compromise. ${ }^{11}$

However, this led to a situation in which it was not clear what role the term was supposed to play and what was its inherent meaning, if it had one in the first place. To fully understand the possible approaches to this issue, one should remember that 'investments' (including contractual rights or not) are already defined in BITs. What has not been settled so far is if this definition of, for example, a contractual right as an investment found in a BIT is also the one relevant for Article 25(1) (which would mean that Article 25 term has no inherent, objective meaning) or this definition only constitutes consent as required by Article 25(1) while 'investment' presents a separate jurisdictional hurdle. The debate became even more complicated because of differing opinions in case-law how is this objective, inherent meaning of 'investment' to be established if the tribunal considers it to indeed exist.

The case-law dealing with these problems is substantial and diverse. It is not possible within the scope of this work to go into all the interesting factual or theoretical subtleties of particular cases. What is possible is to rationalize the general approaches of various tribunals into three groups: a) 'deference to consent'; b) 'benchmark'; and c) 'cumulative' group. In essence, all these approaches are located along the line which starts at total subjectivity and deference to consent, and ends at the strictly objective approach with the need for cumulative fulfilment of additional (varying) objective preconditions in a manner resembling a checklist.

Decisions in the first group ${ }^{12}$ practically equate consent and investment - if the BIT proclaims something to be an investment, this should suffice for all purposes of Article 25(1). The other two groups of decisions share a different starting premise there is something more in Article 25(1) that needs to be fulfilled and that is the requirement of 'investment' which should be ascertained by some objective criteria.

\footnotetext{
${ }^{11}$ Engela C. Schlemmer, 'Investment, Investor, Nationality, and Shareholders', in Peter Muchlinski, Federico Ortino and Cristoph Schreuer (eds), The Oxford Handbook of International Investment Law (OUP 2008) 49, 62-3; Julian D. Mortenson, 'The Meaning of “Investment": ICSID's Travaux and the Domain of International Investment Law’ (2010) 51 Harvard International Law Journal 257, $280 f f$.

12 Azurix Corp. v. Argentine Republic, ICSID Case No. ARB/01/12 (Decision on Jurisdiction, 8 December 2003) 43 ILM (2004) 262; Enron Corporation and Ponderosa Assets, L.P. v. Argentine Republic, ICSID Case No. ARB/01/3 (Decision on Jurisdiction, 14 January 2004) <http://www.asil.org/ilib/Enron.pdf> accessed 15 May 2012; Fraport AG Frankfurt Airport Services Worldwide v. Republic of the Philippines, ICSID Case No. ARB/03/25 (Award, 16 August $2007)<$ http://ita.law.uvic.ca/documents/FraportAward.pdf> accessed 15 May 2012; Biwater Gauff (Tanzania) Limited v. United Republic of Tanzania, ICSID Case No. ARB/05/22 (Award, 24 July 2008)

<http://icsid.worldbank.org/ICSID/FrontServlet?requestType=CasesRH\&actionVal=showDoc\&do cId=DC1589_En\&caseId=C67 $>$ accessed 15 May 2012. Generally, also in: Pantechniki S.A. Contractors \& Engineers v. Republic of Albania, ICSID Case No. ARB/07/2 1 (Award, 30 July 2009) <http://icsid.worldbank.org/ICSID/FrontServlet?requestType=CasesRH\&actionVal=showDoc\&do cId=DC1133_En\&caseId=C113> accessed 15 May 2012.
} 
Reasoning based on objective criteria is usually considered to have originated in Fedax v. Venezuela. ${ }^{13}$ It seems that in early ICSID cases the tribunals were not much willing to deliberate about the issue. ${ }^{14}$ The Fedax tribunal turned to the writings of Professor Schreuer and concluded that the basic features of investment (for Article 25(1) purposes) were a certain duration, a certain regularity of profit and return, assumption of risk, a substantial commitment, and significance for the host State's development. ${ }^{15}$ These criteria were followed by the tribunal in the Salini v. Morocco ${ }^{16}$ case (giving the name to the so-called Salini test), with the exception of the need for certain regularity of profit and return, while also noting the need to assess all these criteria globally, in light of their interdependence. ${ }^{17}$

However, variations that developed in this general approach are not irrelevant. Cases in the 'benchmark' group ${ }^{18}$ suggest that the presence of certain criteria is providing only exemplary guidance for the tribunal - 'benchmarks or yardsticks'19 to help the tribunal in deciding, while it stays as flexible as possible. Cases in the 'cumulative' group state the requirement that all the criteria need to be present in order to find an investment - but they disagree on what these criteria are. Cases in this group revolve around the Salini test, but the number of criteria is either three (Salini test minus 'contribution to the host State'criterion), ${ }^{20}$ four, ${ }^{21}$ five (adding back

\footnotetext{
${ }^{13}$ Fedax N.V. v. Republic of Venezuela, ICSID Case No. ARB/96/3 (Decision on Objections to Jurisdiction, 11 July 1997) 37 ILM (1998) 1378.

14 Campbell McLachlan, Laurence Shore and Matthew Weiniger, International Investment Arbitration: Substantive Principles (OUP 2007) 169-170; Reed, Paulsson and Blackaby (n 8) 68.

${ }^{15}$ Fedax v. Venezuela (n 13) para. 43.

${ }^{16}$ Salini Costruttori S.p.A. and Italstrade S.p.A. v. Kingdom of Morocco, ICSID Case No. ARB/00/4 (Decision on Jurisdiction, 23 July 2001) 42 ILM (2003) 609.

${ }^{17}$ Ibid., para 52. The Salini v. Morocco dispute arose out of claims which two Italian companies, Salini and Italstrade, had against a Moroccan entity (ADM) financed by the Moroccan government regarding the construction of highways for which these companies where contracted by ADM. Moroccan government, inter alia, tried to negate the definition of contractual rights (which these companies had) as investments for ICSID purposes, which was eventually rejected by the tribunal. Salini criteria as described above were defined in the process.

${ }_{18}$ Československa obchodní banka, a.s. v. Slovak Republic, ICSID Case No. ARB/97/4 (Decision on Objections to Jurisdiction, 24 May 1999) 14 ICSID Review (1999) 251; MCI Power Group LC and New Turbine v. Ecuador, ICSID Case No. ARB/03/6 (Award, 31 July 2007) $<$ http://ita.law.uvic.ca/documents/MCIEcuador.pdf $>$ accessed 15 May 2012; RSM Production Corporation v. Grenada, ICSID Case No ARB/05/14 (Award, 13 March 2009) <http://ita.law.uvic.ca/documents/RSMvGrenadaAward.pdf> accessed 15 May 2012.

19 RSM v. Grenada (n 18) para. 241.

${ }^{20}$ Bayindir Insaat Turizm Ticaret Ve Sanayi A.S. v. Islamic Republic of Pakistan, ICSID Case No. ARB/03/29 (Decision on Jurisdiction, 14 November 2005) $<$ http://icsid.worldbank.org/ICSID/FrontServlet?requestType=CasesRH\&actionVal=showDoc\&do cId=DC523_En\&caseId=C27 $>$ accessed 15 May 2012; LESI, S.p.A. and Astaldi, S.p.A. v. People's Democratic Republic of Algeria, ICSID Case No. ARB/05/3 (Decision on Jurisdiction, 12 July 2006) $<$ http://icsid.worldbank.org/ICSID/FrontServlet?requestType=CasesRH\&actionVal=showDoc\&do cId=DC528_Fr\&caseId=C48> accessed 15 May 2012; Víctor Pey Casado and President Allende Foundation v. Republic of Chile, ICSID Case No. ARB/ 98/2 (Award, 8 May 2008) <http://ita.law.uvic.ca/documents/Peyaward.pdf> accessed 15 May 2012; Saba Fakes v. Republic of Turkey, ICSID Case No. ARB/07/20 (Award, 14 July 2009) <http://ita.law.uvic.ca/documents/Fakes_v_Turkey_Award.pdf > accessed 15 May 2012; For a nonICSID case, see Romak S.A. v. The Republic of Uzbekistan, PCA Case No. AA280 (Award, 26 November 2009) <http://ita.law.uvic.ca/documents/ROMAKUZBEKISTANAward26November2009.pdf> accessed 15 May 2012.

${ }^{21}$ Jan de Nul N.V. and Dredging International N.V. v. Arab Republic of Egypt, ICSID Case No. $\mathrm{ARB} / \mathrm{O4} / 13$ (Decision on Jurisdiction, 16 June <http://ita.law.uvic.ca/documents/JandeNuljurisdiction061606.pdf> accessed 15 May 2012.
} 
the 'regularity of profit and return' criterion) ${ }^{22}$ or even six (adding legality and good faith to the Salini criteria). ${ }^{23}$

It is not hard to see that such a confusing state of jurisprudence is seriously infringing the predictability of outcomes and thus also legal certainty. In the end, achieving investment protection before ICSID for a potentially high value contract might depend on the doctrinal inclinations of the arbitral tribunal, and not on settled legal principles. Therefore, it is submitted that there should be a single approach in determining jurisdiction, and in the author's opinion that approach should be an objective, semi-cumulative, three criteria test that will be elaborated below. As a side note, one should be aware that the lack of formal binding precedent doctrine in ICSID arbitration might be an obstacle to ever achieving totally unified approach. However, with the attitude that was exhibited, for example, by the Bayndir and Saba Fakes tribunals and which endorses following established and consistent case-law in comparable situations, ${ }^{24}$ homogeneity of case law can be largely achieved. Such development are already noted and supported in doctrine. ${ }^{25}$

\subsection{The Proposed Model}

It is first necessary to see why the approach should not be based on the total deference to consent. It might seem that such an approach has some compelling arguments to support it. Article 25 (1) of the ICSID Convention simply speaks of disputes arising out of an investment without further qualifications about an investment. Article 25 (4) sanctions the freedom of the contracting State to exclude whole classes of disputes from their consent to jurisdiction and thus clearly confirms the principle of party autonomy. On the basis of such premises, it is not easy to see why then the parties should not be absolutely free to define what an investment is. If contracting States have a strong interest in giving BIT/ICSID arbitration protection to a particular form of transaction, should Article 25 stand in their way? If such protection is under the circumstances important for the economic development of a certain country (for example, as a tool to attract particular foreign businesses) would that not mean that Article 25 would contravene the Preamble of the Convention (which sets economic development as a primary goal) and undermine

\footnotetext{
${ }^{22}$ Joy Mining Machinery Limited v. Arab Republic of Egypt, ICSID Case No. ARB/03/11 (Award, 6 August 2004) 19 ICSID Review (2004) 486; Helnan International Hotels A/S v. Arab Republic of Egypt, ICSID Case No. ARB/05/19 (Decision on Objections to Jurisdiction, 17 October 2006) <http://icsid.worldbank.org/ICSID/FrontServlet?requestType=CasesRH\&actionVal=showDoc\&do cId=DC773_En\&caseId=C64> accessed 15 May 2012.

23 Phoenix Action Ltd v. Czech Republic, ICSID Case No. ARB/06/5 (Award, 15 April 2009) $<$ http://icsid.worldbank.org/ICSID/FrontServlet?request Type=CasesRH\&actionVal=showDoc\&do cId=DC1033_En\&caseId=C74> accessed 15 May 2012.

${ }^{24}$ See Saba Fakes v. Turkey (n 20) para 96.

25 Andrea K. Bjorklund, 'Investment Treaty Arbitral Decisions as Jurisprudence Constante', UC Davis Legal Studies Research Paper No. $158<$ http://ssrn.com/abstract=1319834> accessed 15 May 2012, 266-267; Cristoph Schreuer, 'Diversity and Harmonization of Treaty Interpretation in Investment Arbitration', (2006) 3 Transnational Dispute Management 10, 14; Jan Paulsson, 'International Arbitration and the Generation of Legal Norms: Treaty Arbitration and International Law', (Provisional Issue September 2006) Transnational Dispute Management 13; Thomas W. Wälde, 'The Present State of Research Carried Out By the English-Speaking Section of the Centre for Studies and Research', in New Aspects of International Investment Law (Brill 2006) 140ff; Alexis C. Brown, 'Presumption Meets Reality', (2001) 16 American University International Law Review 1013; Tai-Heng Cheng, 'Precedent and Control in Investment Treaty Arbitration', (2007) 30 Fordham International Law Journal 1048-1050.
} 
its aims? In light of such questions, it can be seen why some tribunals accepted total deference to parties consent or why, for example, Professor Mortenson suggests that whatever parties considered an investment, as long as it is 'colorably economic', should be considered to be an investment for the purposes of Article 25. ${ }^{26}$

But this simply cannot stand. While it is true that establishing whether or not a certain transactions falls within what the parties agreed is an investment is a necessary condition of establishing ICSID jurisdiction, it should not be a sufficient condition. Two main arguments speak against unrestricted deference. Firstly, this would mean that the term 'investment' does not have and can never have any inherent meaning for the purposes of an institution intentionally created to deal with investments. Although one can accept that legal and economic definitions of an investment may differ, this cannot mean that they differ so much that former is actually tabula rasa to be written by the Contracting States over and over again while the latter has well-known (albeit sometimes blurry) borders. Contracting States of the ICSID Convention did not create ICSID in order to resolve all sorts of 'economic' or 'business' disputes, but only 'investment' disputes. This is not to say that creating a new, wide reaching dispute resolution centre aimed at 'business' disputes in general would be illegitimate or unwarranted, but simply that it is not what ICSID is. Trying to 'transform' it to something through (the lack of) jurisdictional thresholds should thus be prevented.

Secondly, one should consider what would be the practical consequences of accepting unrestricted deference. Wide acceptance of economic activities as investments could lead to many transitory and fringe activities suddenly becoming investments. ${ }^{27}$ This would potentially (or even likely) lead to the opening of the floodgates and undesirable massive increase in investment litigation. As the trend of increase in cases is already a constant in international investment arbitration, pushing the process even more could easily lead to the system becoming hopelessly overstretched and, ultimately, inefficient.

In conclusion, establishing if a transaction is an investment for the purposes of a relevant BIT is essential to establish if there is the consent required by the Article 25(1) but not more than that. In order to find this consent, a tribunal needs to interpret the relevant BIT in accordance with the rules of public international law and the circumstances of the particular case, but this analysis remains separate from finding of an 'investment' for the purposes of Article 25.

It is thus necessary to turn to establishing the inherent meaning of that term. It is common ground that certain criteria need to be established in order to 'fill' the term 'investment' with some meaning. Two key issues must be resolved: first, what these criteria should be and second, how one should characterize their nature and mutual interdependence.

As for the number and contents of the criteria to be applied, as seen above, the Salini test is the starting point. However, before dealing with the problem of the actual variant of the test that would be preferable, one can question whether the Salini criteria are to be taken as a starting point at all. Indeed, there are serious conceptual objections to the Salini test, specifically that it is ideologically coloured and also

\footnotetext{
26 Mortenson (n 11) 315.

${ }^{27}$ See Zachary Douglas, The International Law of Investment Claims (CUP 2009) 163-164.
} 
unsuitable to comprise portfolio ${ }^{28}$ investments. ${ }^{29}$ It would be quite legitimate to propose a new, maybe more appropriate test. Still, it is submitted that Salini should be a viable starting point. It is widely (albeit somewhat differently) applied in the case-law, which makes it an obvious choice for creating and maintaining a line of consistent jurisprudence. In addition to that, in the author's opinion, criteria of duration, contribution and risk really do form a core of what should be expected from an investment.

However, this is not the case with the other criteria sometimes proposed. Criteria of legality and good faith, mentioned above, cannot be reconciled with Article 25(1) and should be rejected for reasons well explained in case law. ${ }^{30}$ Regularity of profit and return also seem inadequate as a criterion. If this regularity must be achieved, than this is an unjustifiably high threshold, as the foreign investor is left without protection if its investment failed for commercial reasons, and that should not be relevant in this context. And if it is expected regularity, then this can easily be assimilated with the criterion of risk.

But the situation is not so clear regarding the criterion of host State development. This criterion has strong proponents, some going so far as to consider it a 'crucial' one. ${ }^{31}$ Yet, it should be rejected. It is inherently open to different interpretations and also subject to so much (substantiated) criticism that it can hardly play a meaningful role. Some respected scholars are clearly against the idea of the need to show any particular contribution to the host State apart from general benefits that investments usually bring. ${ }^{32}$ The term itself is very vague. Even if the discussion is limited to just economic development, as opposed to broad notion of 'development', an arbitral tribunal will face itself with numerous possible definitions of what 'economic development' actually is. ${ }^{33}$

There are also other problems related to this criterion. There is no agreement whether this contribution needs to be 'significant' or not. Or how is it supposed to be measured - by the increase of the GDP of the host State, or somehow differently. All these difficult issues were put forward before arbitral tribunals and, regrettably, received different answers. ${ }^{34}$ Not to mention how much more complicated the landscape would become if human rights and similar non-economic variables were also included into the notion of development. ${ }^{35}$ Finally, as some arbitral tribunals

${ }^{28}$ Portfolio investments comprise investments constituted out of acquiring and ownership of shares in a foreign company without the aim of managing that company. See Sornarajah (n 4) 8-10.

29 See, for example, Devanish Krishan, 'A Notion of ICSID Investment', in Todd Weiler (ed), Investment Treaty Arbitration and International Law (Vol. 1, JurisNet LLC 2008) 61.

30 Saba Fakes v. Turkey (n 20) para 112.

31 Amazu A. Asouzu, International Commercial Arbitration and African States - Practice, Participation and Institutional Development (CUP 2004) 263.

32 Kenneth J. Vandevelde, 'The Economics of Bilateral Investment Treaties', 41 Harvard International Law Journal (2000) 469, 492.

3s Ignacio D'Alessio, 'A Comment on ICSID's jurisdictional issues: Problems, Solutions and Recommendations for a Better Understanding in International Commercial Relations' (Research Paper, Vrije Universiteit Amsterdam 2008) <http://ssrn.com/abstract=1153988> accessed 15 May 2012,35

${ }^{34}$ Katia Yannaca-Small, 'Definition of "Investment”: An Open-ended Search for a Balanced Approach', in Katia Yannaca-Small (ed), Arbitration Under International Investment Agreements: A Guide to the Key Issues (OUP 2010) 243, 259-261.

35 Marek Jezewski, 'There is No Freedom without Solidarity: Towards a New Definition of Investment in International Economic Law' Working Paper No. 51/08, SIEL Inaugural Conference Online Proceedings <http://www.ssrn.com/link/SIEL-Inaugural-Conference.html> accessed 15 May 2012, 1, 12ff. 
aptly noted, this criterion is not only difficult to establish but is practically covered by the remaining three, ${ }^{36}$ leaving the arbitral tribunals prone to confuse it with other criteria. $^{37}$

Unfortunately, the issue remains hotly contested in arbitral practice, as illustrated by the decisions of the annulment committees in Malaysia Historical Salvors ${ }^{38}$ (arguing for non-jurisdictional and flexible character of this criterion) and Patrick Mitchell ${ }^{39}$ (arguing for essentiality of this criterion). ${ }^{40}$ Dissenting opinion of judge Mohamed Shahabuddeen in Malaysia Historical Salvors, for example, offers a good illustration of differing positions accepted on this point by developed and developing states. $^{41}$

Although 'development' is the aim stated in the ICSID Convention Preamble, it is submitted that transforming an (optimistic and diplomatic) wording found there into any sort of jurisdictional requirement is not just unusual, but also unwarranted and excessively troublesome. The Preamble remains a useful tool for interpretation and for establishing the aims of the Convention. But these aims are quite sufficiently advanced by applying the remaining three Salini criteria. Thus, regarding the objective criteria to be used, the first three Salini criteria (contribution, certain duration and an element of risk) are the foundation that is needed.

This leads us to the second crucial issue. In the light of the existing jurisprudence, it seems necessary to decide if these three criteria are to be simply 'benchmarks and yardsticks' or their presence needs to be established in each and every case.

It is submitted that if the three above mentioned criteria are accepted as the core of what constitutes an investment, then the tribunal should not treat them as mere guiding examples. These criteria should be present in every case. But this does not mean that the tribunals should drift into an overly strict approach and impose some general minimum 'quantities' of each of the criteria that must always be present. It should be borne in mind, for example, that the very author whose writings were the source of the criteria, Professor Schreuer, warned and criticized against accepting these general features of investment as a strict jurisdictional test. ${ }^{42}$

What the tribunal should do is that it should be attentive to what the Salini $v$. Morocco tribunal stated in addition to setting out the test, and that is the need to interpret the criteria in totality and having regard to the circumstances of a particular case. The tribunal should not be able to find the existence of an investment if one element is lacking. It is truly hard to argue, for example, that a

\footnotetext{
${ }^{36}$ LESI v. Algeria (n 20) para. 72; Bayindir v. Pakistan (n 20) para. 137.

${ }^{37}$ Given (n 5) 487.

${ }^{38}$ Malaysian Historical Salvors, SDN, BHD v. Malaysia, ICSID Case No. ARB/05/10 (Decision on the Application for Annulment, 16 April 2009) <http://icsid.worldbank.org/ICSID/FrontServlet?requestType=CasesRH\&actionVal=showDoc\&do cId=DC1030_En\&caseId=C247 $>$ accessed 15 May 2012.

${ }^{39}$ Patrick Mitchell v. Democratic Republic of the Congo, ICSID Case No. ARB/99/7 (Decision on the Application for the Annulment of the Award, 1 November 2006) <http://ita.law.uvic.ca/documents/mitchellannulment.pdf> accessed 15 May 2012.

${ }^{40}$ For more on this issue see Yannaca-Small (n 34) 259-61.

${ }_{41}$ Malaysian Historical Salvors, SDN, BHD v. Malaysia, ICSID Case No. ARB/05/10 (Dissenting Opinion of Judge Mohamed Shahabuddeen, 19 February 2009) <http://icsid.worldbank.org/ICSID/FrontServlet?requestType=CasesRH\&actionVal=showDoc\&do cId=DC1031_En\&caseId=C247 $>$ accessed 15 May 2012.

${ }^{42}$ Schreuer, The ICSID Convention: A Commentary (n 5) 140.
} 
contract of negligible duration can seriously be considered an investment. On the other hand, what the tribunal should be free to do is to conduct a balancing exercise. It should be free, while taking into account all the circumstances of the case, to decide what extent of fulfilment of each of the criteria is enough.

In the author's opinion, this precludes prescriptive statements such as that investment must have a minimum duration of a certain number of years or any similar 'quantification' of investments. Such requirements, that to some extent resemble a Procrustean bed, simply cannot be reconciled with the flexible approach which is needed. Additionally, one should also bear in mind that one similar 'quantification' threshold for an investment to exist (in the form of minimum value) was explicitly rejected during the drafting of the ICSID Convention. ${ }^{43}$

In summary, a foreign investor seeking to protect his contractual rights as investments before an ICSID should expect two distinct steps in proving that jurisdictional thresholds are met. The first step is establishing that its contractual right is covered by the relevant BIT. Generally, because of the usually broad wording used in BITs, this should not prove to be excessively hard in most cases (some potential issues will be mentioned below when discussing sales contracts). After this step, which establishes consent for the purpose of Article 25, the investor should prove the fulfilment of three criteria - certain duration, contribution and existence of risk, as to fulfil the quintessential conditions for the existence of an 'investment' within the meaning of Article 25(1).

When deliberating about this issue, the tribunal should decisively determine the existence of all three criteria, but it should be flexible in assessing the extent to which these need to be fulfilled. The tribunal should take into account all the relevant circumstances of the particular case, with potential diversity of these not permitting any all encompassing or very specific guidance. If the contract in question is one already recognized in case law as constituting an investment, this should provide a useful guidance and also support the investor's case, but that fact alone should not be decisive. Even if one supports the development of harmonious ICSID jurisprudence, this should not come at the expense of doing justice to the facts of each particular case.

It can be predicted that in most cases what the States envisaged in a BIT as an investment, and what can be an investment for the purposes of Article 25 will coincide. ${ }^{44}$ But not always, and the following section offers a good illustration.

\section{SALES CONTRACTS}

\subsection{General Remarks}

As can be concluded from above, adding new types of contract to the list of usually recognized investments should not be considered to be a finished process. One can be even less sure if a particular contract will be recognized as an investment in individual cases with potentially very differing circumstances. Yet, in contrast to this assertion, there seems to be a widespread trend in legal instruments and

\footnotetext{
${ }^{43}$ Mortenson (n 11) 297-298.

44 Global Trading Resource Corp. and Globex International, Inc. v. Ukraine, ICSID Case No. ARB/09/11 (Award, 11 December 2010) $<$ http://icsid.worldbank.org/ICSID/FrontServlet?request Type=CasesRH\&actionVal=showDoc\&do cId=DC1771_En\&caseId=C660 $>$ accessed 15 May 2012, para. 44.
} 
jurisprudence that ordinary commercial contracts, primarily contracts of sale, cannot fall within the definition of investment. ${ }^{45}$ This trend is largely supported by doctrinal writings as authors emphasize these contracts as examples of what would usually fall out of the scope of protection when discussing definitions of investments in various instruments and for various purposes. ${ }^{46}$

It is submitted that such assertions should be taken with caution and that this general proposition should not be considered valid in all situations. The ratio behind it certainly has merit, in that it aims to prevent unwarranted and highly undesirable stretching of investment protection too far. However, it can be argued that there are situations in which what might be perceived as a sales contract should be recognized to be an investment, mainly due to its close relation with a previous investment already made.

It should also be said that the term 'sales contracts' is here used as a generic term to denote all kinds of trading arrangements which have as their key feature exchange of goods for payment, as opposed to various types of services/labour/production arrangements. In the author's opinion, this group can offer a good view as how the term 'investment' can and should continue to evolve.

An excellent illustration of the general trend of exclusion of sales contracts is provided by the Global Trading and Globex v. Ukraine case. The tribunal, after resorting to previous ICSID decisions, concluded that pure commercial transactions, such as simple purchase and sale contracts, cannot be considered as investments for the purpose of Article 25. ${ }^{47}$ As for the transactions in question in that particular case, which were rather typical trans-boundary CIF sales, the tribunal stated:

... these are each individual contracts, of limited duration, for the purchase and sale of goods, on a commercial basis and under normal CIF trading terms, and which provide for delivery, the transfer of title, and final payment, before the goods are cleared for import into the recipient territory; and that neither contracts of that kind, nor the moneys expended by the supplier in financing its part in their performance, can by any reasonable process of interpretation be construed to be 'investments' for the purposes of the ICSID Convention. ${ }^{48}$

Another example is the often cited non-ICSID case of Petrobart v. Kyrgyz Republic,49 centred on the sale of gas condensate under the ECT. In that case, as is suggested,

\footnotetext{
${ }_{45}$ North American Free Trade Agreement (The NAFTA) (signed on 17 December 1992, entered into force 1 January 1994) 32 ILM (1993) 289 (Parts I-III) 32 ILM (1993) 612 (Parts III-VI), Art. 1139 ; Joy Mining v. Arab Republic of Egypt (n 22) paras. 57-58; OECD, Definition of Investment and Investor in International Investment Agreements (2008) 50.

${ }^{46}$ Paul Szasz, 'A Practical Guide to the Convention on Settlement of Investment Disputes', (1968) 1 Cornell International Law Journal 1, 15; William Rand, Robert N. Hornick and Paul Friedland, 'ICSID's Emerging Jurisprudence: The Scope of ICSID's Jurisdiction', (1986) 19 New York University Journal of International Law and Politics 33, 36; UNCTAD, Scope and Definition (1999) 20; Schreuer, The ICSID Convention: A Commentary (n 5) 139; Raymond Doak Bishop, James R. Crawford and William M. Reisman, Foreign Investment Disputes: Cases, Materials and Commentary (Kluwer International 2005) 344; Rudolph Dolzer and Cristoph Schreuer, Principles of International Investment Law (OUP 2008) 60.

${ }^{47}$ Global Trading and Globex v. Ukraine (n 44) paras. 54-56.

${ }^{48}$ Ibid, para 56 (footnote omitted and emphasis added).

${ }_{49}$ Petrobart Ltd v Kyrgyz Republic, SCC Arbitration Institute Arbitration No. 126/2003 (Award, 29 March 2005) <http://www.asil.org/pdfs/Petrobart-Kyrgyz.pdf> accessed 15 May 2012.
} 
an investment would not exist if examined by an ICSID tribunal applying Fedax and Salini. ${ }^{50}$

The reasoning in the above cases, which should be supported, is not only relevant because it clearly prohibits using ICSID for the purposes of commercial arbitration. It is also relevant because it contains useful starting points in determining which sales contracts actually should be investments for the purposes of Article 25(1). And this is a very interesting issue that (bearing in mind the vast number of sales contracts being concluded and performed every day around the world) deserves careful consideration.

\subsection{Sales Contracts which Deserve Recognition}

Apart from looking at the case law, it is also useful to carefully examine what legal scholars have to say about transactions that should not be considered investments in any case. Here we find such notions as 'non-recurring transactions such as simple sales $(. . .)^{\prime}{ }^{51}$, 'ordinary transaction for purposes of a sale (...) ${ }^{5} 52$ and 'ordinary sales (...) unless some special feature of the transaction could objectively support a subjective stipulation by the parties to that effect.' 53 Thus, both case law and doctrine point in the same direction - there needs to exist something special, something that would elevate the contract of sale to something more than just 'ordinary' or 'simple' one in order for an investment to exist.

In the author's opinion, that special element should be the complexity of the transaction combined with its firm relation to an existing investment in the host State. It is clear that simple trans-boundary sales have no place here. Not only that the case law clearly shows why the rejection of such contracts is justified in the context of Article 25(1), even regardless of the exact objective test one can use, but even establishing consent can easily prove to be an insurmountable obstacle for the claimant. For example, BITs usually speak of investments made in the territory of the host State. ${ }^{54}$ A claimant who is trying to prove that a trans-boundary commercial sale has any meaningful relation with the territory of the host State would indeed be highly unlikely to succeed, even if it can at somehow subsume this transaction into some broader notion of 'contractual rights' as potentially found in a BIT.

But let us now turn to a different situation. For example, a foreign investor establishes a production facility in the host State. It might be, let us say, a pharmaceuticals producer aiming at supplying the host State health system, or using some advantages of the business climate in the host State to use it as a base for exporting its products. There should be no difficulty in finding that the production facility is an investment. But what should be the status of sales contracts concluded by the foreign investor to market the products of the facility?

\footnotetext{
${ }^{50}$ McLachlan, Shore and Weiniger (n 14) 170.

${ }^{51}$ Schreuer, The ICSID Convention: A Commentary (n 5) 139.

${ }_{52}$ Rudolph Dolzer, 'The Notion of Investment in Recent Practice', in Steve Charnovitz et al (eds), Law in the Service of Human Dignity: Essays in Honour of Florentino Feliciano (CUP 2005) 261, 263.

${ }^{53}$ Szasz (n 46) 15.

${ }^{54}$ Douglas (n 27) 171-2; Jeswald W. Salacuse, 'Towards a Global Treaty on Foreign Investment: The Search for a Grand Bargain', in Norbert Horn and Stefan M. Kröll (eds), Arbitrating Foreign Investment Disputes: Procedural and Substantive Legal Aspects (Kluwer Law International 2004) 51, $68-9$.
} 
From the outset the situation seems to be different from the one involving transboundary contracts. The potential territoriality criterion should no longer be an obstacle in framing the transaction within the BIT definition of an investment. What is more, many BITs include the example of a 'claim associated with an investment' in their illustrative lists of potential investments. It is quite conceivable that the claimant could here find strong support in proving that the BIT covers its transaction, and thus provides necessary consent for arbitration.

But this still leaves the second step. There must be certain duration, risk, and contribution by the claimant. ${ }^{55}$ It can safely be stated that an individual, one-off transaction should remain out of the scope of investment protection even in these factual circumstances. Its duration is still practically negligible in the context of investments. That can also be said about the assumed risk. Even with a flexible mindset that a tribunal should assume, simple sales which were thrown out through the door regarding pure trans-boundary sales should in any case not be allowed to come back through the window in this different context.

However, the situation should change once the transaction under scrutiny becomes significantly more complex, despite remaining in its essence a sales contract. An example of such a transaction is a high-value, long-term supply contract. In the example of a pharmaceutical company, this can mean supplying medicines to the health system of the host State for a number of years. It would involve a large number of recurring transactions under the general umbrella of a contractual framework. It is submitted that in such circumstances the test to be used in the second step of establishing jurisdiction can indeed be satisfied.

Bearing in mind the specific circumstances of a factual situation as presented (and more on that will be said below), the three criteria can be fulfilled to such an extent that it can be hard to see how not to regard a contract as an investment. What if this long-term contract was actually a key motive for the foreign investor to come to the host State in the first place? If the contract fails because the host State breached standards of protection prescribed in the BIT, it is not only that the risk of losing the profit from that particular contract materialized, it is also possible that there is the risk that the whole initial, primary investment is now at stake. Similarly, when discussing contribution, it is not only that the investor contributed, let us say, a particular quantity of goods to fulfil a particular contract, but in a sense it 'contributed' the whole initial investment, which was made exactly to contribute to fulfilling the contract. But even if the contract is not crucial in the sense indicated above, it should be sufficient to show that the three criteria are fully fulfilled and that the contract can be readily distinguished from ordinary contracts as described in Global Trade and Globex v. Ukraine or Joy Mining v. Egypt.

This is especially true if one takes into account, as the tribunal should, a special circumstance which exists here, and that is the close connection of the transaction with a recognized investment. This is an excellent example of a situation where the concept described as 'general unity of an investment operation' ${ }^{56}$ comes into play. This concept is based on a premise that an overall project may qualify as an

\footnotetext{
${ }_{55}$ An excellent example of 'pure' sale of pharmaceuticals which failed to satisfy these elements (despite long duration and recurrent transactions) and was thus not found to be an investment can be found in The Republic of Italy v. The Republic of Cuba, Italy-Cuba BIT Ad Hoc Arbitration (Final Award, 15 June 2008), < http://italaw.com/documents/Italy_v_Cuba_FinalAward2008.pdf > accessed 15 May 2012, paras 212-21.

${ }^{56}$ UNCTAD, Investor-State Dispute Settlement and Impact on Investment Rulemaking (2007) 21.
} 
investment even though certain individual transactions comprising it do not, and that disputes arising out of these related transactions (even though they are not investments in themselves) still can be seen as arising out of an investment. ${ }^{57}$ Reasoning of the $C S O B$ tribunal explains this well:

Hence, a dispute that is brought before the Centre must be deemed to arise directly out of an investment even when it is based on a transaction which, standing alone, would not qualify as an investment under the Convention, provided that the particular transaction forms an integral part of an overall operation that qualifies as an investment. ${ }^{58}$

It should be noted that non-ICSID cases also support such a conclusion. For example, in the Franz Sedelmayer ${ }^{59}$ case it was emphasized that it was the close relation to an already existing investment that was crucial in determining whether some other right was an investment too. ${ }^{60}$

Therefore, the claimant has a strong additional argument that the contract, in essence, 'emanates' from an established investment and that this primary investment serves as a 'leverage' to propel it into the scope of protected investments.

Of course, despite establishing a possible theoretical model for recognition of such sales contracts as investments, it is impossible in advance to define sufficient duration or sufficient risk, or sufficient level of complexity to differentiate simple from complex transactions. What should also be borne in mind is that different branches of industry operate in different conditions. It can well be the case that the manufacturer will not have a long term, well-defined contractual arrangement. Instead, it might have to rely on sales which are occasional and far apart, but of very high value and of crucial importance for its business. Is there still an investment if such an isolated sales contract comes under scrutiny of an arbitral tribunal? Can high value and importance be that special element that will differentiate it from an 'ordinary' sale? It is hard to answer in abstract terms. This illustrates how tribunals can face truly hard cases in practice. But the general approach should remain the same.

In conclusion, when dealing with sales contracts, arbitral tribunal should remain committed to the prevailing approach that ordinary commercial sales are not investments for the purpose of Article 25(1). But this should not be the general conclusion for all sales transactions. It should be qualified with an exception that more complex and longer lasting transactions associated with existing recognized investments warrant recognition as investments themselves.

\section{CONCLUDING REMARKS}

\footnotetext{
${ }^{57}$ Schreuer, The ICSID Convention: A Commentary (n 5) 141.

${ }^{58} \mathrm{CSOB}$ v Slovakia (n 18) para 72.

${ }^{59}$ Franz Sedelmayer v Russian Federation, Germany-Russia BIT Ad Hoc Arbitration (Award, 7 July 1998 ) <http://ita.law.uvic.ca/documents/sedelmayer-russia.pdf> accessed 15 May 2012.

${ }^{60}$ McLachlan, Shore and Weiniger (n 14) 168.
} 
The issues analysed in this paper show that the topic of contractual rights in investment law is a dynamic one. In dealing with these rights in arbitral practice what should be sought is an adequate balance between flexibility and predictability. It is thus useful to propose certain guidelines for the future that should help in achieving such aim. Some of these are of a more general nature, while some deal with particular groups of issues examined above.

Two general remarks seem warranted. Firstly, the divergence in the ICSID jurisprudence regarding very important issues of jurisdiction is a reason for serious concern. While achieving uniformity of practice through introducing binding precedents is hardly practically feasible, or even desirable, ICSID tribunals should be aware of their role in remedying this situation. Striving for uniformity in a reasonable manner should be the aim pursued in practice. Secondly, arbitrators dealing with contractual rights as potential investments should keep an open mind and be receptive to the ever changing forms in which foreign investments take place. The historical development of the notion of investment is a good illustration how flexible this area can be. But this open-mindedness is also warranted by the very essence of the idea of investment protection. Excessive restrictiveness can only lower the incentives for investing and in that way infringe the main goal - economic development.

As for recognizing which contracts are investments, apart from further harmonization of definitions in legal instruments which would certainly be beneficial, the way forward seems to be in accepting a common approach for determination if the conditions found in Article 25(1) are fulfilled. The approach that should be accepted is based on distinction between establishing consent (to be found in a BIT) and establishing if there is an investment, as both are distinctly required by Article 25(1). While the first issue remains largely in the area of general treaty interpretation, more guidelines can be given for the second element. The test to be applied should be based on the criteria of duration, risk and contribution. These should be fulfilled to a sufficient extent in every case, cumulatively, but the tribunal should be free to determine what the sufficient extent is. In committing this balancing exercise, it should pay attention to the specific circumstances of each particular case.

Regarding sales contracts, the existing general view that ordinary sales are not investments for the purpose of Article 25 should remain predominant. But this reasoning cannot be extended to all sales contracts. When a sales contract (which is, as the first condition, protected under the BIT) forms a part of a broader investment enterprise, clustered around a recognized investment, and by its other features also complies with the established test for recognition under Article 25(1), then it should be considered to be an investment and protected accordingly.

It is, of course, not easy to achieve the observance of these guidelines in practice. But it is something to be aimed for. It is the author's opinion that application of the above guidelines would promote fair, balanced and reasonably predictable outcomes in deciding various issues that come before investment arbitration tribunals. And such outcomes would increase the protection of both legal and economic interests of investors and host States. 